\title{
NOTE ON TRANSLITERATION AND TRANSLATION
}

All TRANSLATIONS IN THIS BOOK ARE MY OWN UNLESS OTHERWISE INDICATED. Working between four languages in the archives has made me particularly grateful for the clarity of the Library of Congress system, which I have used for transliteration, note, and bibliographic standards from Azerbaijani, Russian, and Ukrainian into English. I have favored Ukrainian over Russian spellings for locations that sit in contemporary Ukraine (Kyiv and Kharkiv, for instance, rather than Kiev and Khar'kov/ Kharkov), but retained original spellings in quoted excerpts. I have also used commonly accepted Western spellings of certain proper names, such as Maxim Gorky rather than Maksim Gorkii, and Trotsky, not Trotskii. 

SPATIAL REVOLUTION 
